\title{
The Effects Of Reference Groups, Motivation, And Learning On The Used Of Whatsapp
}

\author{
Diah Isnaini Asiati ${ }^{1}$, M. Trisujiyanto ${ }^{1}$ and Titi Rapini ${ }^{2}$ \\ $\left\{{ }^{1}\right.$ diah_isnaini@yahoo.com $\}$ \\ ${ }^{1}$ Departement of Managment, Universitas Muhammadiyah Palembang, Palembang Indonesia \\ ${ }^{2}$ Departement of Management, Universitas Muhammadiyah Ponorogo, Ponorogo, Indonesia
}

\begin{abstract}
The development of technology gave rise to many social media whose utilization was welcomed quickly by the market. One of the most famous social media is using Whatsapp (WA). This study aimed to determine the influence of reference, motivation, and learning groupson the used of WA. The design was developed associative design. The population of this research was all the head of family (KK) of Seberang Ulu II Plaju Palembang. The number of samples was determined by $171 \mathrm{KK}$ selected by cluster sampling. The required data was primary data with questionnaire data collection method. Further data was analyzed using multiple linear regression. The results of the study indicated that (1) consumer reference groups provided strong pressure in terms of WA usage, (2) motivated consumers to communicate, seek information, and seek entertainment through the used of WA, (3) WA was considered to provide easy, simple, fast, and practical so that consumers will learn to use it.
\end{abstract}

Keywords: Reference Group Factors, Motivation Factors, Learning Factors, Using WA

\section{INTRODUCTION}

In recent years, technological advancement has provided tremendous facilities for the market for the used of the Internet for various activities. Even the used of the internet for social networking puts Indonesia in 2 nd ranked as a country with the most social networking community. In addition to being a media of social networking developers, the internet can also be used to search for information, dowload / upload, chat, communication, transactions, games, and others. The impact of further development is the growth of various communication media. Currently people do not only use the phone, but also Line, WA, Facebook, Instagram and others to communicate, seek information and entertainment. Pre-research interview conducted showed $52 \%$ of people using Whatsapp (WA) as a social networking media, and others using facebook, Line, or HP. The used of WA was mostly done for practical reasons, simple, easy to learn, or because of the influence of relationships that exist around the consumer.

WA users come from all people [1], age, gender, geography, marital status, occupation, education, and income. [2] described the used of WA that tended to create addictive feelings associated with certain psychological conditions such as feelings of shame, mood, loneliness, 
and stress. The used of WA had proved to be a stress reliever for people under 35 , living in cities, and living as civil servants, with relatively low incomes [1] Unfortunately, specifically [3] found, the students had not been able to utilize WA users optimally for their educational purposes. In fact, [4] found that the used of WA did not only provide social benefits and relaxation needs, but could also meet the need for certain information, knowledge, and understanding. That is why a more comprehensive study of what factors affect consumers to use WA applications in various social interactions.

\section{LITERATURE REVEW}

Schiffman and Kanuk [5] described consumer behavior as a process through which a person seeks, buys, uses, evaluates, and acts post-consumption of products, services and ideas that were expected to meet their needs. Overall [6] suggested factors that influenced behavior could be as a stimulus to marketing, other stimuli, buyer characteristics, and purchasing decision processes. Furthermore, on the characteristics of buyers, there were cultural, social, personal and psychological factors.

Among social factors, reference groups hadan important role as human beings as social beings. According to [7], others, individually or in groups, have a strong urge to influence others. Groups could mean friendship groups, shopping groups, work groups, or other groups [5][8] calls it formal and informal groups, primary and secondary groups, or groups of aspirations and dissociations.

According to [9] the reference group is an individual or group of people who are considered to have significant relevance to a person in terms of evaluating, predating, or in behavior. The reference group will provide standards and values that will affect a person's behavior and serve as a reference for someone in purchasing and consumption decisions. There are three kinds of influence of the reference group [8] a) the normative influence, namely the influence of the reference group on a person through social norms to be obeyed or followed. This influence will be strong if there is pressure to comply with existing norms, social acceptance, and if the purchased product is seen as a symbol of social darinorma b) the effect of value expression, ie the effect that purchasing certain products will make consumers feel appreciated or admired, and c) the influence because the reference group is considered to have good knowledge and information.

Sari [10] proves the influence of the reference group on the use of social media Line. [11] also proves the power of this group's influence on the use of internet cafes. Further Natalia and [12] prove the influence of the reference group on the used of 3G. Based on existing theories and studies, the hypothesis was formulated:

\section{H1: There was an effect of reference groups on the used of WA}

Motivation is one of psychological element of consumer. Motivation can be described as a driving force within the individual that forces them to take a buying action that is believed to satisfy the need [5]. According to [8] motivation arises because of the needs felt by consumers. Needs arise because consumers feel the discomfort between what should be felt and what it really feels. The perceived need encourages a person to take action to meet those needs. This is what is termed as motivation. 
Kotler and Keller [6] writes that Herzberg developed a two-factor theory that distinguishes dissatisfiers (factors that cause dissatisfaction) and satisfiers (factors that cause satisfaction). The absence of dissatisfiers alone is not enough, otherwise satisfiers must exist skillfully to motivate purchases. This theory has two implications. First, the seller should try as best as possible to avoid dissatisfiers, although it is not causing the product to malfunction, but can easily lead to unsold products. Secondly, the factory must identify the main satisfiers or motivators of the purchase in the market to then provide the factor of the satisfiers. Satisfiers will make a big difference to what brands customers buy. [9] distinguish between rational motivation and emotional motivation. The study of the influence of motivation on the used of social media has been done by [12] Hence the hypothesis was formulated:

\section{H2: There was an effect of motivation on the used of WA}

Another psychological factor that affects buying behavior was learning. According to [6] learning is indicated by behavioral changes arising from experience. Learning is generated through a work blend of stimulus, clue, response, and reinforcement:

- A powerful stimulus is an internal stimulus that drives action.

- The clue is a stimulus that directs the stimulus if it is consistent with the expectations of the

consumer. Ads, product packaging, and prices are cues that affect consumers to meet their needs.

- Response is a way of reacting individuals to encouragement or cues. If considered good, then

consumers will buy it.

- Reinforcement is something that increases the tendency of consumers to behave in the future due to

the stimulus.

[8] mentions that, marketers have an interest in teaching consumers to recognize the advertising of their products or services, remember it, love it, and still buy it. [11] and [12] have proven the influence of learning on social media usage decisions. That is why the hypothesis is formulated:

\section{H3: There was a learning effect on the used of WA}

\section{METHODS}

This research used associative design [13]. The variables used that was measured using each indicator as shown in the following table:

1 The reference group (X1), was any individual or group that significantly affected the consumers using WA. The indicators used friends, family, and neighbors.

2 Consumer Motivation (X2), which was the consumer driving force using WA. Indicators used communication, information, and entertainment.

3 Learning (X3), was behavior change to keep using WA due to experience. The indicators used easy, simple, fast, and practical.

4 Purchase Decision (Y), was consumer actions evaluate the used of WA. The indicator used the choice of services, hoists, and dealers. 
The research population [13] was the community of 14 Ulu Plaju, Palembang. Samples were taken as many as 171 respondents in Cluster Sampling. The main data of the research was primary data [14] derived from the questionnaire.Furthermore, after testing to ensure the feasibility of the data, then performed the analysis. The analysis technique used multiple linear regression [15].

\section{RESULTS AND DISCUSSION}

\subsection{Research Results}

\subsubsection{Characteristics of Respondents}

Table 1. Respondent Characteristics

\begin{tabular}{|c|c|c|c|}
\hline \multirow[t]{2}{*}{ No } & \multirow[t]{2}{*}{ Characteristics } & \multicolumn{2}{|c|}{ Total } \\
\hline & & Person & $\%$ \\
\hline \multirow[t]{3}{*}{1} & Gender & & \\
\hline & Man & 76 & 44,44 \\
\hline & Woman & 95 & 55,56 \\
\hline \multirow[t]{5}{*}{2} & Age & & \\
\hline & 16-19 Years & 25 & 14,62 \\
\hline & 20-30 Years & 91 & 53,21 \\
\hline & 31-40 Years & 43 & 25,14 \\
\hline & Above 41 Years & 12 & 7,2 \\
\hline \multirow[t]{4}{*}{3} & Education & & \\
\hline & SMA & 101 & 59,1 \\
\hline & $\mathrm{S} 1$ & 49 & 28,6 \\
\hline & $\mathrm{S} 2 / \mathrm{S} 3$ & 21 & 12,3 \\
\hline \multirow[t]{4}{*}{4} & Income & & \\
\hline & < Rp. 1.500 .000 & 9 & 5,3 \\
\hline & $\begin{array}{l}\text { Rp. } 1.500 .000-\text { Rp. } \\
3.000 .000\end{array}$ & 124 & 72,5 \\
\hline & > Rp. 3.000 .000 & 38 & 22,2 \\
\hline \multirow[t]{5}{*}{5} & Social Media Used & & \\
\hline & WA & 81 & 47,37 \\
\hline & Line & 24 & 14,03 \\
\hline & Facebook & 27 & 15,79 \\
\hline & Headphone Number & 39 & 22,81 \\
\hline
\end{tabular}

\subsubsection{The test result}

The value of $\mathrm{R}$ showed the relationship between the reference, motivation, and learninggroup with buying decision of 0.77 . Adjusted R Square number was 0,586, indicating that reference, motivation, and learninggroup variable that was only able to explain the changed of variable buying decision by $58,6 \%$ (Table 2). While the rest of $41.4 \%$ was explained by other variables that was not included in this study.

Table 2. Table 2. Multiple Correlation and Coefficient of Determination

\begin{tabular}{lcccr}
\hline Model & R & R Square Adjusted R Square Std. Error of the Estimate \\
\hline 1 & $0,770^{\mathrm{a}}$ & 0,593 & 0,586 & 0,972
\end{tabular}


Table 3. F Test Results

\begin{tabular}{|c|c|c|c|c|c|c|}
\hline \multicolumn{2}{|c|}{ Model } & Sum of Squares & Df & Mean Square & $\mathrm{F}$ & Sig. \\
\hline 1 & Regression & 229,870 & 3 & 76,623 & 81,114 & $0,000^{\mathrm{a}}$ \\
\hline & Residual & 157,756 & 167 & 0,945 & & \\
\hline & Total & 387,626 & 170 & & & \\
\hline
\end{tabular}

According to Table 3, the value of Sig $(0.000)<0.05$, which meant that Ho was rejected. There was a significant influence simultaneously, between reference, motivation, and learninggroups on the used of WA

Table 4. . T Test Result

\begin{tabular}{|c|c|c|c|c|c|}
\hline \multirow[t]{2}{*}{ Model } & \multicolumn{2}{|c|}{$\begin{array}{l}\text { Unstandardized } \\
\text { Coefficients }\end{array}$} & \multirow[t]{2}{*}{$\begin{array}{c}\text { Standardized } \\
\text { Coefficients }\end{array}$} & \multirow[t]{2}{*}{$T$} & \multirow[t]{2}{*}{ Sig. } \\
\hline & $\mathrm{B}$ & Std. Error & & & \\
\hline 1 (Constant) & 2,531 & 0,675 & & 3,753 & 0,000 \\
\hline $\mathrm{X} 1$ & 0,412 & 0,070 & 0,429 & 5,851 & 0,000 \\
\hline $\mathrm{X} 2$ & 0,228 & 0,098 & 0,231 & 2,317 & 0,022 \\
\hline $\mathrm{X} 3$ & 0,123 & 0,059 & 0,186 & 2,083 & 0,039 \\
\hline
\end{tabular}

Based on Table 4, the following interpretations could be given:

The reference group variable had an influence value of 0.412 . A positive $t$ value indicated that the effect was positive and unidirectional. Sig value $(0,000)<$ probability value $(0,05)$, it meant that there was significant influence of reference group to consumer decision using WA.

Motivation variable had an influence value of 0.228 . The positive $t$ value indicated that the effect was positive and unidirectional. Sig value $(0,022)<$ probability value $(0,05)$, it meant that there was significant influence of motivation to consumer decision using WA.

The learning variable had an influence value of 0.123 . The positive $t$ value indicated that the effect was positive and unidirectional. Sig value $(0,039)<$ probability value $(0,05)$, it meant that there was significant influence of learning to consumer decision using WA.

\subsection{Discussion of Research Results}

\subsubsection{Influence of Reference, Motivation, and LearningGroupon the Used of WA}

Hypothesis testing proved that there was a significant effect simultaneously, between reference, motivation, and learning groups on the used of WA. Reference, motivation, and learninggroups, together affect purchasing decisions. This result was in line with Kotler's (2016) opinion, that marketing stimuli, other stimuli, buyer characteristics, and purchasing decision processes have an effect on consumer buying decisions. Reference group was one of the variable in social factor which was one of consumer characteristic. Motivation and learning were in the psychological factors of consumers.

These results were in line with [10], that the reference group affects the loyalty of instant messaging users. Support results as well as given to [11], that reference and learning groups have a significant effect on the used of internet cafe. Likewise, if associated with [12], that 
reference, motivation and learning groups influence on the decision on the used $3 \mathrm{G}$ Technology.

Associated with the indicators used to measure the three variables, respondents indicated a relatively high agreement, so that the purchase decision was dominated by the respondent's consent.

\subsubsection{Reference group}

The reference group was shown to have a significant positive effect on the used of WA. Support is given to Kotler's opinion (2016). No consumer is not involved in the group, and group members build interaction with the continuum low to high. Interaction was often done the assessment of a particular product. The members of the reference group would be attracted to each other to support their purchasing decisions, including support for the used of WA.

Associated with the results of [10], the reference group variables equally positively influence and obtain responses with strong consent by consumers. Similarly with [11], and [12]. Based on the variable indicator, consistent results were indicated by the dominance of consumer consent

The study was dominated by respondents aged 20-40 years, with the majority of high

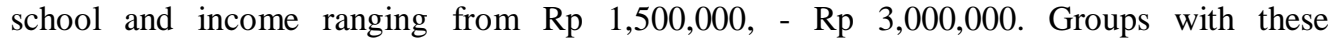
characteristics were similar to those described by [1]. Generally they took advantage of the WA that had not been maximized because of the new entertainment medium [2]. The used of WA due to the influence of the reference group, according to [8] stronger give normative pressure and expression of value compared with information. Therefore need to be studied more about the utilization of WA more leverage, especially in education through reference group.

\subsubsection{Motivation}

Motivation proved to have a significant positive effect on the used of WA. [6] states, that motivation is one of the psychological elements of consumers, internal elements of consumers who interact with the stimulus of marketing influence on consumer purchasing decisions. These results reinforced the findings Natalia and [12], in this study the motivation to be variable, although both had a significant influence, compared to previous research, this study had a deeper influence.

Respondents stated that motivation received a high approval answer, through communicative encouragement, information acquisition, and entertainment (whose approval was relatively lower). Booming used of WA in Indonesia caused incoming information that was crowded and it made consumers feel less comfortable. Nevertheless, [2] proves WA's utilization will recur because it is considered to reduce stress [1]. Moreover, according to [9], motivation is not only provides rational benefits, but also benefits hedonis. It needed further study on the used of WA to be more rational.

\subsubsection{Learning}

Learning had a significant positive effect on the used of WA. According to [6] states, that when consumers act consumers actually learn. According to learning theory, learning is generated by controlled behavior, stimuli, clues, responses, and reinforcement. When using WA, consumers actually exercise behavioral control, follow instructions, respond, and gain reinforcement. Linked to [11] learning variables are equally positive and gain strong approval 
by consumers. In the previous study, learning became an indicator, whereas in this study the learning became variable. Although both had significant influence over previous studies, this study had a deeper influence.

Respondents considered learning to provide an easy, simple, easy to learn, and practical WA experience. Respondents of this study was the majority of high school education with age below 40 years. A group that was welcome and enthusiastic about the things that connoted progress. Especially according to [4] utilization of WA can meet the needs of cognitive, affective, social, and tension relief. In conjunction with cognitive needed, it was necessary to find the maximum WA media.

Based on this research proved that the variable reference, motivation, and learninggroup had their own role and influence in influencing purchasing decision. Because the variable reference, motivation, and learning group was an important part / aspect for consumers to determine purchasing decisions. So based on this study known reference group was the first part that determines consumer purchasing decisions, then depending on the consumer's own motivation, and continued with how consumers did learning on its evaluation indetermine the purchase decision. Thus if the reference, motivation, and learning group together would form an influence that almost represents the whole of the consumer's consideration in determining the purchase decision.

In this study, reference, motivation, and learning group variables could only explain the purchase decision as much as $58.6 \%$. This meant there was still a chance and the role for other variables of $41.4 \%$ which could be used as influence variable to purchase decision. Thus it was suggested to re-do similar research by increasing the number of variables.

\section{CONCLUSIONS AND IMPLICATIONS}

\subsection{Conclusion}

WA became one of the most popular social media. The strength of the influence of the used of this media was the consumer reference group, which had a high frequency in interacting with consumers so to give a strong influence on its used. Consumer motivation also encouraged the used of WA through its benefits to communicate, seek information and entertainment. In addition, learning had an important meaning for consumers, the used of WA was considered easy, simple, fast, and practical that could change consumer behavior to consistent use it.

\subsection{Implications}

Reference, motivation, and learninggroup influenced on the used of WA in this research, however it was advisable to add another variable, because there was still possibility of other independent variable which influence to purchasing decision. In addition, in relation to education, needed to look for methods of utilizing WA media more appropriate for educational goals.

We hope you find the information in this template useful in the preparation of your submission. 


\section{REFERENCES}

[1] S. Shanmugapriya dan A. Priya, "A study on impact of using whatsapp on reduction stress," International Journal of Current Research and Modern Education, vol. 1, no. 2, pp. 66-79, 2016.

[2] N. Singh, N. Chopra dan J. Kaur, "A study to analyze relationship between psychological behavioral factors on whats app addiction among youth in jalandhar district in punjab," European Journal of Business and Management, vol. 6, no. 37, pp. 269-274, 2014.

[3] A. M. M. Gasaymeh, "University students use on whatsapp and their perception regarding its possible integration into their education," Global Journal of Computer Science and Technology : G Interdisciplinary, vol. 17, no. 1, pp. 1-11, 2017.

[4] Akinlosotu, "Predictors of whatsapp consumtion among undergraduate students of economics in ambrose alli university, ekpoma," African Research Review, vol. 10, no. 2, pp. 290-301, 2016.

[5] L. Schiffman dan L. L. Kanuk, Perilaku Konsumen, 7 penyunt., Jakarta: PT Indeks, 2008, p. 522.

[6] P. Kotler dan K. L. Keller, Marketing Management, 15 penyunt., England: Pearson Education Limited, 2016, p. 714.

[7] R. D. Blackwell, P. W. Miniard dan J. F. Engel, Consumer behavior, Singapore: Nelson Education, Ltd, 2012, p. 639.

[8] U. Sumarwan, Perilaku konsumen, Bogor: Ghalia Indonesia, 2014, p. 468.

[9] Ristiyanti dan John, Perilaku konsumen, Yogyakarta: Andi, 2005.

[10] M. Y. Sari, "Pengaruh kelompok referensi, kepercayaan merek, dan kepuasan konsumen terhadap loyalitas merek pesan instan," Program Studi Fakultas Ekonomi, pp. 11-22, 2015.

[11] A. Setyarini, "Analisis faktor-faktor yang mempengaruhi keputusan pemakaian jasa warnet di sekitar kampus universitas sebelas maret surakarta," Ar Risalah, vol. 10, no. 28, pp. 197-221, 2012.

[12] L. Handrijaningsi dan D. Natalia, "Analisis faktor -faktor yang mempengaruhi keputusan penggunaan tknologi 3G depok," dalam Psikologi, Ekonomi, Sastra, Arsitektur \& Sipil, Depok, 2009.

[13] Sugiyono, Metode penelitian kuantitatif, kualitatif, dan R\&D, Bandung: Alfabeta, 2016.

[14] H. Umar, Riset pemasaran dan kepuasan konsumen, Jakarta: Gramedia, 2005.

[15] I. Hasan, Statistik 1, Jakarta: Bumi Aksara, 2013.

[16] A. T. N, "University students' use of whatsapp and their perceptions regarding its possible integration into their education," Global Journal of Computer Science and Technology : G Interdisciplinary, vol. 17, no. 1, pp. 1-11, 2017.

[17] R. D. Blackwell, P. W. Miniard dan J. F. Engel, Consumer behavior, Singapore: Nelson Education, Ltd, 2012, p. 637. 